\title{
ESSENTIAL OILS IN WELLNESS CENTERS: OVERVIEW ON EUROPEAN UNION LEGISLATION, POTENTIAL THERAPEUTIC EFFECTS AND TOXICITY
}

\author{
ANA FLAVIA BURLEC ${ }^{1 \#}$, IRINA MACOVEI ${ }^{1 *}$, ALINA SĂCĂRESCU ${ }^{2}$, ANDREIA CORCIOVĂ $^{1 *}$, \\ CORNELIA MIRCEA ${ }^{1}$, CRISTINA ELENA IANCU ${ }^{1}$, OANA CIOANC $\breve{A}^{1}$, MONICA HĂNCIANU ${ }^{1}$

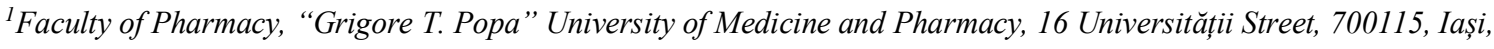 \\ Romania \\ ${ }^{2}$ Faculty of Medicine, "Grigore T. Popa” University of Medicine and Pharmacy, 16 Universității Street, 700115, Iași, \\ Romania
}

*corresponding author: acorciova@yahoo.com

${ }^{\#}$ Authors with equal contribution.

Manuscript received: May 2020

\begin{abstract}
Essential oils or volatile oils are natural products that have a large series of uses in the food and cosmetic sectors. According to their intended use, essential oils are subjected to various European guidelines that aim to protect the health and safety of consumers. Volatile oils present important biological activities, some of the most known being their antimicrobial properties, but other potential therapeutic indications for such products have been more recently suggested, as well. However, they are not necessarily harmless and can present an important sensitizing potential. Essential oils have been administered through different routes, including inhalations and skin applications, in the treatment of stress and anxiety. Regardless of the route of administration, aromatherapy deeply relies on the sense of smell and its connection with the limbic system. Nevertheless, outside of the principles of aromatherapy, numerous scientific studies have revealed their potential beneficial implications in Alzheimer's and other neurological disorders.
\end{abstract}

\section{Rezumat}

Uleiurile esențiale sau uleiurile volatile sunt produse naturale care au o serie largă de utilizări în sectorul alimentar şi în cel cosmetic. În funcție de utilizarea propusă, uleiurile esențiale sunt supuse diferitelor reglementări europene care au ca scop protejarea sănătății și a siguranței consumatorilor. Uleiurile volatile prezintă activități biologice importante, unele dintre cele mai cunoscute fiind proprietățile lor antimicrobiene, dar au fost sugerate și alte potențiale indicații terapeutice pentru astfel de produse. $\mathrm{Cu}$ toate acestea, ele nu sunt neapărat inofensive și pot prezenta un potențial de sensibilizare important. Uleiurile esențiale sunt administrate pe diferite căi, incluzând inhalațiile şi aplicaţiile cutanate, în tratamentul stresului şi al anxietății. Indiferent de calea de administrare, aromaterapia se bazează pe simțul mirosului și pe legătura acestuia cu sistemul limbic. $\mathrm{Cu}$ toate acestea, în afara principiilor aromaterapiei, numeroase studii științifice au relevat potențialele lor implicații benefice în boala Alzheimer și alte tulburări neurologice.

Keywords: essential oils, EU legislation, antimicrobial, aromatherapy, central nervous system

\section{Introduction}

Essential oils (EOs), also known as volatile oils, are defined in the European Pharmacopoeia as "odorous products" that generally have a complex chemical composition and are obtained from well-defined plant materials through three main processes: steam distillation, dry distillation, or other appropriate mechanical processes that don't involve heating [14]. They can usually be found in oil cells, glandular hairs, as well as in secretion cavities of different aromatic plants [23].

EOs consist mainly of mixtures of hydrocarbons and their oxygenated derivatives. Taking into account their chemical structure, EOs contain terpenes, which can either be mono-, sesqui- and diterpenes, while triterpenes can rarely be detected, and oxygenated compounds such as alcohols, aldehydes, ketones, lactones, acids and esters [40, 49].

Around 3000 EOs have been defined so far, out of which 300 are considered important from a commercial point of view, being widely used in the food and cosmetic industries [41].

EOs can be used through several methods, but they are generally administered in small amounts by inhalation, massage or skin applications, and in rare cases can also be given internally, being found in different supplements or medicines. Inhalation and skin applications of volatile oils have long been utilized in different types of aromatherapy, so as to improve mood and allegedly restore spiritual balance [3].

Many studies have shown the important therapeutic potential that volatile oils possess. Among some of the 
FARMACIA, 2020, Vol. 68, 6

most important biological actions noted for these mixtures are the antibacterial, antifungal, antiviral, antioxidant, anti-inflammatory, neuroprotectant and antidiabetic activities [31, 43, 56].

Given their pleasant smell, such volatile oils are commonly found in cosmetics, since they cover the unpleasant aroma of different excipients used in the production of such goods [50]. Moreover, volatile oils are also used as such in spa and wellness centres, because of their scent and some of their potential therapeutic effects, as well as for marketing reasons [63]. However, EOs are not necessarily harmless, even though they are natural products. Taking into account the selected administration route, several adverse reactions have been described in the scientific literature. If considering skin applications and inhalation of products containing EOs, different cases of dermatitis and sensitization, as well as respiratory disorders have been reported so far. Moreover, adulteration, as well as incorrect production, storage and labelling of products containing EOs can also lead to clinical manifestations of toxicity [34]. Consequently, the need for appropriate standardization and legislation regarding the use of EOs is essential for keeping consumers safe.

\section{EU legislation on EOs}

The major producers of EOs worldwide are China, India, Indonesia, Sri Lanka and Vietnam, while the most important producers in Europe are France and Germany. However, the EU appears to be the world's main importer of EOs, with France, Germany, and the UK being the most noteworthy traders. Given the growing interest of individuals in pursuing a healthy lifestyle, as well as the increase in the use of EOs in fields ranging from the food sector to the spa industry, a rise in the demand of EOs has been noticed, which is expected to continue growing [9].

In spa and wellness centres, EOs and some of their isolated constituents can be employed in many activities such as aromatherapeutic massages and baths, inhalations, sauna, air aromatization are found in different cosmetic preparations that are used in these health facilities [39]. Some of the most popular EOs used in such centres are those obtained from lavender (Lavandula angustifolia), bergamot (Citrus aurantium var. bergamia), German chamomile (Matricaria chamomilla), eucalyptus (Eucalyptus globulus), frankincense (Boswellia caterii), damask rose (Rosa damascena), tea tree (Malaleuca alternifolia) and peppermint (Mentha piperita var. vulgaris) [24, 50]. Since in wellness centres essential oils are often found in cosmetics, two important EU regulations for such products are represented by the Registration, Evaluation, Authorisation and Restriction of Chemicals (REACH) and the EU Cosmetics Regulation (Regulation (EC) No 1223/2009 of The European Parliament and of The Council) [19]. This last regulation defines the "cosmetic product" as "any substance or mixture intended to be placed in contact with the external parts of the human body (epidermis, hair system, nails, lips and external genital organs) or with the teeth and the mucous membranes of the oral cavity with a view exclusively or mainly to cleaning them, perfuming them, changing their appearance, protecting them, keeping them in good condition or correcting body odours" [47]. As stated, this regulation only focuses on products that interact with the skin and mucous membranes, but mentions that a product meant to be inhaled should not be considered a cosmetic. Annexes II and III of the aforementioned regulation specify which EOs and individual constituents are prohibited for use in cosmetics, as well as certain conditions of use or restrictions concerning such substances or mixtures. Annex III includes 26 potentially allergenic fragrances, most of which are constituents of EOs. Some of the most known fragrances belonging to this list are cinnamal, citral, citronellol, eugenol, farnesol, geraniol, d-limonene and linalool. For such compounds, it must be declared on the packaging or in the attached or enclosed leaflet if the concentration is higher than $0.01 \%$ in rinse-off products such as shower gels and higher than $0.001 \%$ in leave-on products such as massage oils and creams [47, 50]. Regarding cosmetic products containing EOs, the Council of Europe has also published several documents with recommendations related to the use of camphor, eucalyptol and menthol, especially in products for infants, which is advised against [21].

The International Fragrance Association (IFRA) also sets certain standards and recommendations regarding the safe use of fragrances. Through its members, IFRA impacts almost $80 \%$ of the international fragrance industry in terms of production volume [58]. At European level, IFRA works on issuing important guidelines (e.g. EFEO/IFRA Guidelines on Substance Identification and Sameness of Natural Complex Substances (NCS) under REACH and CLP) together with one of its partners, the European Federation of Essential Oils (EFEO), which is a non-profit association that aims to protect and encourage the production and trade of EOs and related products throughout the continent [22].

Important quality requirements of EOs are also set through International Organization for Standardization (ISO) standards. There are more than 100 published ISO standards under the direct responsibility of ISO/TC 54 that is in charge of the standardization of the analysis methods and specifications for EOs. Such standards refer to general rules for packaging, storage, labelling, determination of various characteristics (e.g. refractive index, optical rotation, miscibility in ethanol), as well as to content evaluation [55].

It is important to mention that if the product containing EOs cannot be included in the description of a cosmetic product, then it will only be regulated by the General Products Safety Directive (Directive 2001/95/EC of the European Parliament and of the Council of 3 
December 2001), which is a default directive that is rather easier to comply with [16]. Nonetheless, products such as candles and diffusers that contain EOs still have to be safe for the consumers to use [29, 33]. Considering the substance responsible for the fragrance of such products, the EU Regulation (EC) No 1272/ 2008 on classification, labelling and packaging of substances and mixtures (CLP) might be applicable and therefore, the label must be in accordance with the established provisions [29, 48]. Depending on each country, other standards and recommendations could also be set for products containing volatile oils [21]. Therefore, consumers must pay appropriate attention to labels and identify the intended use of products containing EOs so as to avoid counterfeit, adulterated or unsuitable products and implicitly, potential health risks.

\section{Benefits vs. toxicity of EOs}

It is well known that EOs have many biological activities, out of which their antibacterial, antifungal and antiviral properties are the most frequently mentioned. They are also characterized by having an intense skin permeation capacity, being often used as sorption promoters for drugs [56]. Apart from these, literature

reported several other biological activities that are in a close relationship with the chemical composition of EOs obtained from different species. Effects of EOs may also vary depending on the route of administration: oral, topical or inhalation. Table I includes beneficial activities of EOs frequently used in wellness centres. Given the subject covered by the present work, only in vivo studies focusing on topical administration and inhalation were selected. A large number of EOs showed a broad-spectrum inhibitory activity over microorganisms, as demonstrated by in vitro tests against several types of human pathogens. Some of these EOs were obtained from species such as Artemisia cana, Achillea clavennae, Cyperus longus, Copaifera officinalis, Foeniculum vulgare, Juniperus phoenicea, Mentha piperita, Nigella sativa, Pimpinella anisum, Rosmarinus officinalis, Salvia officinalis and Syzygium aromaticum [56]. Having such exceptional antimicrobial activities, several EOs were already tested, showing promising results regarding their applicability as preservatives in cosmetic formulations, alone or in combination with synthetic preservatives. These EOs were obtained from species such as Artemisia afra, Calamintha officinalis, Laurus nobilis, Eucalyptus globulus and Salvia officinalis [18].

Table I

Beneficial activities of EOs

\begin{tabular}{|c|c|c|c|c|}
\hline Species & Major compounds & Route of administration & Biological activity & Ref. \\
\hline $\begin{array}{l}\text { Citrus } \\
\text { bergamia }\end{array}$ & $\begin{array}{c}\text { Limonene }(45.45 \%), \\
\text { linalyl acetate }(23.10 \%)\end{array}$ & $\begin{array}{l}\text { Inhalation, } 400 \mu \mathrm{L} \text { EO in } 400 \mathrm{~mL} \\
\text { water diffused using ultrasound } \\
\text { waves/clinical trial }\end{array}$ & $\begin{array}{c}\text { Stress reduction, improve scores } \\
\text { for negative emotions and fatigue }\end{array}$ & [62] \\
\hline $\begin{array}{l}\text { Citrus } \\
\text { sinensis }\end{array}$ & $\begin{array}{l}\text { Limonene }(92 \%) \text {, } \\
\text { myrcene }(3 \%)\end{array}$ & $\begin{array}{l}\text { Inhalation, } 2 \mathrm{~mL} \text { EO diffused by an } \\
\text { electrical aroma diffuser activated } \\
\text { for } 2 \mathrm{~min} \text { every } 10 \mathrm{~min} / \text { clinical trial }\end{array}$ & $\begin{array}{l}\text { Anxiolytic by reducing salivary } \\
\text { cortisol and pulse rate }\end{array}$ & [46] \\
\hline \begin{tabular}{|l|} 
Eucalyptus \\
globulus
\end{tabular} & $\begin{array}{l}\text { 1,8-cineole }(61.46 \%), \\
\text { limonene }(13.68 \%)\end{array}$ & $\begin{array}{c}\text { Inhalation, } 3 \%(\mathrm{v} / \mathrm{v}) \text { EO in almond } \\
\text { oil/clinical trial }\end{array}$ & $\begin{array}{l}\text { Pain relief and blood pressure reduction } \\
\text { after total knee replacement surgery }\end{array}$ & {$[32]$} \\
\hline \multirow[t]{2}{*}{$\begin{array}{l}\text { Lavandula } \\
\text { angustifolia }\end{array}$} & $\begin{array}{c}\text { Linalyl acetate }(31.78 \%), \\
\text { linalool }(25.56 \%)\end{array}$ & Aerosolized 5 - $20 \mu \mathrm{L} / \mathrm{BALB} / \mathrm{c}$ Mice & $\begin{array}{l}\text { Anti-inflammatory in bronchial } \\
\text { asthma }\end{array}$ & [59] \\
\hline & $\begin{array}{l}\text { Linalyl acetate }(35.35 \%) \\
\text { linalool }(33.25 \%), \\
\text { camphor }(17.77 \%)\end{array}$ & $\begin{array}{c}\text { Inhalation of } 2-3 \text { drops of EO for } \\
15 \mathrm{~min} / \mathrm{clinical} \text { trial }\end{array}$ & $\begin{array}{l}\text { Treatment of acute migraine } \\
\text { headache }\end{array}$ & {$[51]$} \\
\hline $\begin{array}{l}\text { Lavandula } \\
\text { stoechas }\end{array}$ & $\begin{array}{l}\text { Alpha-terpineol, } \\
\text { terpinen-4-ol, } \\
\text { linalool, } \\
\text { alpha-pinene, } \\
\text { beta-pinene }\end{array}$ & $\begin{array}{c}\text { Topical, local baths (7 EO drops/4 L } \\
\text { water)/clinical trial }\end{array}$ & $\begin{array}{c}\text { Wound healing in episiotomy } \\
\text { (anti-redness, anti-inflammatory) }\end{array}$ & {$[60]$} \\
\hline $\begin{array}{l}\text { Matricaria } \\
\text { chamomilla }\end{array}$ & $\begin{array}{c}\text { Bisabolone oxide A }(62.35 \%) \\
\text { bisabolol oxide A }(15.54 \%) \\
\text { chamazulene }(2.05 \%)\end{array}$ & $\begin{array}{c}\text { Topical, massages with EO in } \\
\text { sesame oil } 3 \text { times/day/clinical trial }\end{array}$ & $\begin{array}{c}\text { Analgesic and restoring physical } \\
\text { function in treatment of knee } \\
\text { osteoarthritis }\end{array}$ & {$[54]$} \\
\hline $\begin{array}{l}\text { Mentha } \\
\text { piperita }\end{array}$ & $\begin{array}{l}\text { Menthone }(17.7 \%), \\
\text { cineol }(6.34 \%), \\
\text { limonene }(6.03 \%)\end{array}$ & $\begin{array}{c}\text { Inhalation, } 0.1 \mathrm{~mL} 10 \% \text { EO in } 10 \\
\text { mL water infused into the nebulizer } \\
\text { of the ventilator/clinical trial }\end{array}$ & $\begin{array}{c}\text { Reduction of nausea and vomiting } \\
\text { after open-heart surgery }\end{array}$ & {$[38]$} \\
\hline
\end{tabular}

However, apart from these valuable properties, EOs may also possess a rather significant toxicity potential. Therefore, in order to ensure only human health improvement and well-being for EOs usage, strict regulations regarding their use are needed.
EOs may be dangerous to human health if they are accidentally ingested or inadequately used. For example, even if the accidental ingestion of the anti-mosquito citronella oil by young children did not show very high toxicity, the use of traditional topical remedies containing camphor, menthol and eucalyptol caused 
convulsions in children aged between 2 months and 6 years [42].

Furthermore, cutaneous toxicity of EOs is more frequently reported and has been known for a very long period of time. The phenomena that may appear could be phototoxic dermatoses or allergic contact dermatitis. Phototoxic reactions occur mainly as a consequence of psoralens or furanocoumarins that are present in some EOs followed by a skin reaction enhanced by heat, humidity and sun/UV light exposure. For example, bergamot and other citrus oil skin applications may frequently cause berloque dermatitis. Moreover, bergamot EO contains a compound called 5-methoxypsoralen (bergapten), which in combination with UV-light exposure was observed to induce skin cancer [4]. Other EOs found to be responsible for potential phototoxic dermatoses are cerdarwood, rosemary, eucalyptus, petitgrain, neroli, yarrow, anise and ylangylang [34]. As for the allergic episodes, there are several compounds in EOs that were found to have an allergenic potential, out of which there are already 26 known allergens of odorous substances that must be mentioned on the list of ingredients for cosmetic products [61]. These substances were already mentioned in the first part of the article and are included in annex III of the Regulation (EC) No 1223/2009.

Another important aspect for the safe use of EOs is their storage, as it is already known that oxidation of some of their components in the presence of light, air and humidity may enhance their toxic properties. Several studies conducted by Hausen et al. on tea tree EO suggest that the oxidation forms that appear during prolonged storage are the main allergenic factors. Moreover, the freshly distilled tea tree EO did not show any sensitizing capacity. The same authors concluded that the tea tree EO components that could be responsible for the allergic reaction were: terpinolene, $\alpha$-terpinene, ascardiole and 1,2,4-trihydroxymethane [26, 27]. Taking these aspects into consideration, EOs should always be stored in the refrigerator or in a cold, dark place [34]. For the safe use of EOs, a well-balanced risk-benefit assessment is crucial to be defined, but given their complex chemical composition and great variability, this task represents a great challenge for scientists and health policy authorities.

\section{Aromatherapy and how EOs impact the central nervous system}

"Aromatherapy" is a notion which commonly describes the use of EOs in skin massages or in the ambient air. However, medical aromatherapy has a more precise definition and states that the sole purpose of using such a method is to determine a psychological and physiological reaction of the organism [52]. The last decade revealed increased medical interest in aromatherapy and nowadays conventional medicine does not regard this method as pseudoscientific anymore $[3,17$,
52]. This is due to the fact that it becomes more and more obvious that aromatherapy can have a great influence upon major organ systems like the central nervous system and there are several studies that reach such conclusions $[1,17,30]$.

Through inhalation or massages, EOs penetrate the skin and mucosa. Once they enter the systemic circulation, they are also able to reach the brain and even cross the blood brain barrier. EOs constituents can therefore be in direct contact with important nervous structures and modulate the function of neurons $[1,3,15]$. It appears that active compounds from EOs with small molecular size and high lipophilicity, such as certain terpenes, have the highest brain blood barrier penetration. This information is valuable because it can help further research focus on this type of compounds, which apparently have a greater impact on the central nervous system $[1,2]$.

The antioxidant role of EOs plays an important part in neuroprotection [2]. Oxidative stress is deeply involved in the pathogenesis of Alzheimer's disease, in which certain pathophysiologic mechanisms such as $\beta$ amyloid induced neural loss, mitochondrial dysfunction and accumulation of tau associated neurofibrillary tangles can be observed [10]. Such EOs with antioxidant properties are those obtained from Cinnamomum zeylanicum, Ocimum basilicum, Pinus halepensis, Prunus dulcis, Salvia officinalis, Lavandula angustifolia and Juniperus communis [10-13, 20, 25, 45, 57]. It must be mentioned that their antioxidant property is not only valued in relation to Alzheimer's disease, but their use also shows great promise in the treatment of other types of dementias and neurodegenerative diseases and even in mild cognitive impairment. The fact that EOs seem to be able to slow down the pathogenesis of neurological diseases that are linked to oxidative stress could be a step forward for the prevention of these diseases. However, further studies are required in order to demonstrate that using EOs and practicing aromatherapy on a regular basis has a significant impact in delaying the progression of these conditions or even help in preventing or stopping their evolution $[10,64,66]$. Besides their action on oxidative stress, EOs also seem to inhibit cholinesterases. This is important because in Alzheimer's disease and other types of dementia there is a depletion of acetylcholine. Studies have shown that the effect EOs have on acetylcholinesterase or butyrylcholinesterase leads to the inhibition of the hydrolytic degradation of acetylcholine and, by doing so, the levels of this neurotransmitter are increased. The conventional therapeutic strategy in Alzheimer's disease focuses on drugs such as rivastigmine and donepezil, which have an inhibitory action on cholinesterases. Using EOs that have the same effect could lower the doses needed for conventional drugs. Furthermore, EOs could also be used for those patients who cannot tolerate the adverse effects of the commonly 
prescribed medication [7, 10, 37]. The inhibition of cholinesterases has been proved for EOs such as those extracted from: Juniperus communis, Salvia leriifolia, Polygonum hydropiper, Citrus limonum and Mentha spicata [5-7, 12, 35].

Regardless of the route of administration of EOs (inhalation or skin massages), aromatherapy deeply relies on the sense of smell and its connection with the limbic system. From the primary olfactory cortex there are projections to important structures, such as the orbital prefrontal cortex, amygdala, hypothalamus, basal ganglia and hippocampus. Through olfaction, EOs can therefore trigger modifications in those structures in the brain which dictate human behaviour, the functioning of the autonomic nervous system and pain perception $[52,53]$.

The modulation of nociception by EOs at the central nervous system level is far from being understood. The hypothesis is that compounds from these oils influence glutamatergic transmission and inhibit the $\alpha$-amino-3-hydroxy-5-methyl-4-isoxazolepropionic acid (AMPA), N-methyl-D-aspartic acid (NMDA) and kainate receptors. Experimental models have shown that Lavandula angustifolia, Salvia sclareae and Mentha spicata EOs possess analgesic action and could be used in those diseases that involve chronic pain [17, 36]. In what concerns the autonomic nervous system, it appears that Juniperus communis EO increases the parasympathetic activity and this has important consequences, such as reducing heart rate and blood pressure. This proves that aromatherapy is a viable treatment strategy for people with increased sympathetic activity like those suffering from anxiety [44]. The anxiolytic effect seems to be connected to the $\gamma$ aminobutyric acid A (GABAA) receptor at least for some EOs, like the one obtained from Ferulago angulate [8]. It must be noted that when the EO is administered by skin massages, the sense of touch and the sensory pathways also become important and the anxiolytic effect is emphasized. This form of administration was shown to significantly help with behavioural and psychological symptoms of dementia [65]. Other EOs can induce a state of anxiety, producing a raise in blood pressure or breathing rate by increasing the sympathetic activity. Their use should be avoided in people with anxiety, but they can be useful in various conditions, for example in treating hypotension. One such oil which increases sympathetic activity is Jasminum sambac EO [28].

In addition to the aforementioned effects of EOs, the anticonvulsive properties (some of them) possess and their benefits in sedation and sleep should be noted. Plants containing volatile oils with such properties are Ocimum basilicum and Rosa damascene [17].

The impact of aromatherapy on the central nervous system is yet to be understood and more clinical trials need to be conducted, given that many experiments on animal models proved successful. Many EOs that are already being used in wellness centres were shown to have properties that can influence the brain and help in several neurological conditions. The mechanism of action of such substances in the central nervous system is very complex and can vary a lot from one EO to another. Consequently, taking a step further into characterizing the action of such oils on human subjects, as well as refining the concept of "medical aromatherapy" and standardizing the method in which it can be applied in spa and wellness centres and rehabilitation clinics could prove to be extremely beneficial for the general healthcare $[3,52]$.

\section{Conclusions}

EOs have long been used in different therapeutic approaches over centuries, due to their biological properties, such as antibacterial, antifungal and antiviral. Nonetheless, recent studies have also emphasized the benefit of the use of such oils for different neurological and cardio-vascular conditions as well. However, such mixtures, or their isolated compounds can also possess a significant toxicity potential, especially when misused. Therefore, different types of guidelines and regulations are now available throughout the European Union which are meant to keep consumers safe. Moreover, further clinical studies could deepen our knowledge on how EOs impact the human body and how they could be more appropriately and frequently used for the treatment or prevention of different diseases, in accordance with their proven efficacy.

\section{Conflict of interest}

The authors declare no conflict of interest.

\section{References}

1. Agatonovic-Kustrin S, Chan CKY, Gegechkori V, Morton DW, Models for skin and brain penetration of major components from essential oils used in aromatherapy for dementia patients. J Biomol Struct Dyn., 2020; 38(8): 2402-2411.

2. Agatonovic-Kustrin S, Kustrin E, Morton DW, Essential oils and functional herbs for healthy aging. Neural Regen Res., 2019; 14(3): 441-445.

3. Ali B, Al-Wabel NA, Shams S, Ahamad A, Khan SA, Anwar F, Essential oils used in aromatherapy: A systemic review. Asian Pac J Trop Biomed., 2015; 5(8): 601-611.

4. Averbeck D, Averbeck S, DNA photodamage, repair, gene induction and genotoxicity following exposures to $254 \mathrm{~nm} \mathrm{UV}$ and 8-methoxypsoralen plus UVA in a eukaryotic cell system. Photochem Photobiol., 1998; 68(3): 289-295.

5. Avram S, Mernea M, Bagci E, Hritcu L, Borcan LC, Mihailescu DF, Advanced structure-activity relationships applied to Mentha spicata L. subsp. spicata essential oil compounds as AChE and NMDA ligands, in comparison with donepezil, galantamine and memantine - 
new approach in brain disorders pharmacology. CNS Neurol Disord - Drug Targets, 2017; 16(7): 800-811.

6. Ayaz M, Junaid M, Ullah F, Sadiq A, Khan MA, Ahmad W, Shah MR, Imran M, Ahmad S, Comparative chemical profiling, cholinesterase inhibitions and antiradicals properties of essential oils from Polygonum hydropiper L: A preliminary anti-Alzheimer's study. Lipids Health Dis., 2015; 14: 141: 1-12.

7. Ayaz M, Sadiq A, Junaid M, Ullah F, Subhan F, Ahmed J, Neuroprotective and anti-aging potentials of essential oils from aromatic and medicinal plants. Front Aging Neurosci., 2017; 9: 168: 1-16.

8. Bagci E, Aydin E, Mihasan M, Maniu C, Hritcu L, Anxiolytic and antidepressant-like effects of Ferulago angulata essential oil in the scopolamine rat model of Alzheimer's disease. Flavour Fragr J., 2016; 31(1): 70-80.

9. Barbieri C, Borsotto P, Essential Oils: Market and Legislation. In: Potential of Essential Oils. InTech; 2018.

10. Benny A, Thomas J, Essential oils as treatment strategy for Alzheimer's Disease: Current and future perspectives. Planta Med., 2019; 85(3): 239-248.

11. Csakvari AC, Lupitu A, Bungău S, Gîtea MA, Gîtea D, Țiţ DM, Copolovici L, Nemeth S, Copolovici D, Fatty acids profile and antioxidant activity of almond oils obtained from six Romanian varieties. Farmacia, 2019; 67(5): 882-887.

12. Cioanca O, Hancianu M, Mihasan M, Hritcu L, Antiacetylcholinesterase and antioxidant activities of inhaled Juniper Oil on amyloid beta (1-42)-induced oxidative stress in the rat hippocampus. Neurochem Res., 2015; 40(5): 952-960.

13. Cioanca O, Mircea C, Hritcu L, Trifan A, Marius M, Aprotosoaie AC, Robu S, Gille E, Hancianu M, In vitro - In vivo correlation of the antioxidant capacity of Salviae aetheroleum essential oil. Farmacia, 2015; 63: 34-39.

14. Council of Europe, The European Pharmacopoeia $8^{\text {th }}$ Edition (Ph.Eur.); 2014.

15. Czar K, The effects of aromatherapy on alertness in an inclusion setting. The Corinthian, 2009; 10: 7: 111-122.

16. Directive 2001/95/EC of the European Parliament and of the Council of 3 December 2001 on general product safety, https://eur-lex.europa.eu.

17. Dobetsberger C, Buchbauer G, Actions of essential oils on the central nervous system: An updated review. Flavour Fragr J., 2011; 26(5): 300-316.

18. Dreger M, Wielgus K, Application of essential oils as natural cosmetic preservatives. Herba Pol., 2013; 59(4): 142-156.

19. Entering the European market for essential oils, Published 2020www.cbi.eu.

20. El Euch SK, Hassine DB, Cazaux S, Bouzouita N, Bouajila J, Salvia officinalis essential oil: Chemical analysis and evaluation of anti-enzymatic and antioxidant bioactivities. South African J Bot., 2019; 120: 253-260.

21. European Directorate for the Quality of Medicines \& HealthCare, Guidance on essential oils in cosmetic products, 2016, www.edqm.eu.

22. European Federation of Essential Oils, www.efeo.eu/.

23. Evans WC, Trease and Evans' Pharmacognosy. 16 ${ }^{\text {th }}$ ed. Saunders Elsevier; 2009.
24. Exporting essential oils for aromatherapy to Europe, 2018, www.cbi.eu.

25. Gradinariu V, Cioanca O, Gille E, Aprotosoaie AC, Hritcu L, Hancianu M, The chemical profile of basil biovarieties and its implication on the biological activity. Farmacia, 2013; 61: 632-639.

26. Hausen B, Degradation products of monoterpenes are the sensitizing agents in tea tree oil. Am J Contact Dermat., 1999; 10(2): 68-77.

27. Hausen BM, Evaluation of the main contact allergens in oxidized tea tree oil. Dermatitis, 2004; 15(4): 213-214.

28. Hongratanaworakit T, Stimulating effect of aromatherapy massage with jasmine oil. Nat Prod Commun., 2010; 5(1): 157-162.

29. https://businesscompanion.info.

30. Jimbo D, Kimura Y, Taniguchi M, Inoue M, Urakami K, Effect of aromatherapy on patients with Alzheimer's disease. Psychogeriatrics, 2009; 9(4): 173-179.

31. Jugreet BS, Suroowan S, Rengasamy RRK, Mahomoodally MF, Chemistry, bioactivities, mode of action and industrial applications of essential oils. Trends Food Sci Technol., 2020; 101: 89-105.

32. Jun YS, Kang P, Min SS, Lee JM, Kim HK, Seol $\mathrm{GH}$, Effect of eucalyptus oil inhalation on pain and inflammatory responses after total knee replacement: a randomized clinical trial. Evid Based Complement Alternat Med., 2013; 2013: 502727: 1-7.

33. Legislation affecting aromatherapists and product designers, https://ifaroma.org.

34. Lis-Balchin $\mathrm{M}$, The safety issue in aromatherapy. In: Aromatherapy Science: A Guide for Healthcare Professionals. Pharmaceutical Press, 2006: 75-92.

35. Liu B, Kou J, Li F, Huo D, Xu J, Zhou X, Meng D, Ghulam M, Artyom B, Gao X, Ma N, Han D, Lemon essential oil ameliorates age-associated cognitive dysfunction via modulating hippocampal synaptic density and inhibiting acetylcholinesterase. Aging (Albany NY), 2020; 12(9): 8622-8639.

36. López V, Nielsen B, Solas M, Ramírez MJ, Jäger AK, Exploring pharmacological mechanisms of lavender (Lavandula angustifolia) essential oil on central nervous system targets. Front Pharmacol., 2017; 8: 280: 1-8.

37. Ma Y, Yang MW, Li XW, Yue JW, Chen JZ, Yang MW, Huang X, Zhu LL, Hong FF, Therapeutic effects of natural drugs on Alzheimer's disease. Front Pharmacol., 2019; 10: 1355: 1-20.

38. Maghami M, Afazel MR, Azizi-Fini I, Maghami M, The effect of aromatherapy with peppermint essential oil on nausea and vomiting after cardiac surgery: A randomized clinical trial. Complement Ther Clin Pract., 2020; 40: 101199: 1-7.

39. Michalak M, Aromatherapy and methods of applying essential oils. Arch Physiother Glob Res., 2018; 22(2): 25-31.

40. Moghaddam M, Mehdizadeh L, Chemistry of essential oils and factors influencing their constituents. In: Soft Chemistry and Food Fermentation. Elsevier; 2017: 379-419.

41. Nazzaro F, Fratianni F, Coppola R, De Feo V, Essential oils and antifungal activity. Pharmaceuticals, 2017; 10(4): 86: 1-20.

42. Nchinech N, Elgharbi A, Aglili FZ, Kriouile Y, Cherrah Y, Mdaghri AA, Serragui S, Mésusage traditionnel du 
camphre: un danger oublié pour les enfants (à propos de 2 cas). Pan Afr Med J., 2019; 32: 1-5.

43. Păduraru DP, Coman F, Ozon EA, Gherghiceanu F, Andronic O, Ion D, Stănescu M, Bolocan A, The use of nutritional supplement in romanian patients attitudes and beliefs. Farmacia, 2019; 67(6): 10601065.

44. Park JS, Effects of Juniper essential oil on the activity of autonomic nervous system. Biomed Sci Lett., 2017; 23(3): 286-289.

45. Postu PA, Sadiki FZ, El Idrissi M, Cioanca O, Trifan A, Hancianu M, Hritcu L, Pinus halepensis essential oil attenuates the toxic Alzheimer's amyloid beta (1-42)-induced memory impairment and oxidative stress in the rat hippocampus. Biomed Pharmacother., 2019; 112: 1-8

46. Pour FF, Arman S, Jafarzadeh M, Effect of aromatherapy with orange essential oil on salivary cortisol and pulse rate in children during dental treatment: A randomized controlled clinical trial. Adv Biomed Res., 2013; 2(1): 10.

47. Regulation (EC) No 1223/2009 of The European Parliament and of the Council of 30 November 2009 on cosmetic products, 2009. https://eur-lex.europa.eu.

48. Regulation (EC) No $1272 / 2008$ of the European Parliament and of the Council of 16 December 2008 on classification, labelling and packaging of substances and mixtures, 2008. https://eur-lex.europa.eu.

49. Robu S, Romila A, Dumitriu Buzia O, Spac AF, Diaconu C, Tutunaru D, Lisa E, Nechita A, Contribution to the Optimization of a Gas Chromatographic Method by QbD Approach used for Analysis of Essential Oils from Salvia officinalis. Revista de Chimie, 2019; 70(6): 2015-2020.

50. Sarkic A, Stappen I, Essential oils and their single compounds in cosmetics - a critical review. Cosmetics, 2018; 5(1): 11: 1-21.

51. Sasannejad P, Saeedi M, Shoeibi A, Gorji A, Abbasi M, Foroughipour M, Lavender essential oil in the treatment of migraine headache: a placebo-controlled clinical trial. Eur Neurol., 2012; 67(5): 288-291.

52. Schneider R, Singer N, Singer T, Medical aromatherapy revisited - Basic mechanisms, critique, and a new development. Hum Psychopharmacol., 2019; 34(1): e2683: 1-10.

53. Sela L, Sobel N, Human olfaction: a constant state of change-blindness. Exp Brain Res., 2010; 205(1): 13-29.

54. Shoara R, Hashempur MH, Ashraf A, Salehi A, Dehshahri S, Habibagahi Z, Efficacy and safety of topical Matricaria chamomilla L. (chamomile) oil for knee osteoarthritis: A randomized controlled clinical trial. Complement Ther Clin Pract., 2015; 21(3): 181-187.

55. Standards by ISO/TC 54, www.iso.org.

56. Tariq S, Wani S, Rasool W, Shafi K, Bhat MA, Prabhakar A, Shalla AH, Rather MA, A comprehensive review of the antibacterial, antifungal and antiviral potential of essential oils and their chemical constituents against drug-resistant microbial pathogens. Microb Pathog., 2019; 134: 103580: 1-20.

57. Tepe AS, Ozaslan M, Anti-Alzheimer, anti-diabetic, skin-whitening, and antioxidant activities of the essential oil of Cinnamomum zeylanicum. Ind Crops Prod., 2020; 145: 1-8.

58. The International Fragrance Association (IFRA), https://ifrafragrance.org/.

59. Ueno-lio T, Shibakura M, Yokota K, Aoe M, Hyoda T, Shinohata R, Kanehiro A, Tanimoto M, Kataoka M, Lavender essential oil inhalation suppresses allergic airway inflammation and mucous cell hyperplasia in a murine model of asthma. Life Sci., 2014; 108(2): 109-115.

60. Vakilian K, Atarha M, Bekhradi R, Chaman R, Healing advantages of lavender essential oil during episiotomy recovery: A clinical trial. Complement Ther Clin Pract., 2011; 17(1): 50-53.

61. Vigan M, Essential oils: Renewal of interest and toxicity. Eur J Dermatology., 2010; 20(6): 685-692.

62. Watanabe E, Kuchta K, Kimura M, Rauwald HW, Kamei T, Imanishi J, Effects of bergamot (Citrus bergamia (Risso) Wright \& Arn.) essential oil aromatherapy on mood states, parasympathetic nervous system activity, and salivary cortisol levels in 41 healthy females. Complement Med Res., 2015; 22(1): 43-49.

63. Wuttke M, Cohen M, Spa retail. In: Understanding the Global Spa Industry. Elsevier; 2008: 208-220.

64. Xu P, Wang K, Lu C, Dong L, Gao L, Yan M, Aibai $\mathrm{S}$, Yang Y, Liu X, The protective effect of lavender essential oil and its main component linalool against the cognitive deficits induced by D-galactose and aluminum trichloride in mice. Evid Based Complement Alternat Med., 2017; 2017: 7426538: 1-12.

65. Yoshiyama K, Arita H, Suzuki J, The effect of aroma hand massage therapy for people with dementia. $J$ Altern Complement Med., 2015; 21(12): 759-765.

66. Zhu LY, Gao YS, Song LZ, Li SF, Qian JQ, Research on improving memory impairment of blue lavender volatile oil. Zhongguo Zhong Yao Za Zhi., 2017; 42(24): 4819-4826. 